\title{
ISSUES OF REVISING THE APPROACH TO THE EDUCATION OF ARCHITECTS AND ENGINEERS WHEN MOVING TO A PROFESSIONAL STANDARD
}

\section{ВОПРОСЫ ПЕРЕСМОТРА ПОДХОДА К ОБРАЗОВАНИЮ АРХИТЕКТОРОВ И ИНЖЕНЕРОВ ПРИ ПЕРЕХОДЕ НА ПРОФЕССИОНАЛЬНЫЙ СТАНДАРТ}

\author{
USTYUGOVA, Natalia V. ${ }^{* 1}$; POLYANSKAYA, Irina L.² \\ 1,2 Tyumen Industrial University, Construction Institute, Department of Design of Buildings and Urban \\ Construction, 4 Lunacharskiy Str., zip code 625001, Tyumen - Russian Federation
} (phone: +73452283660 )

* Corresponding author

e-mail: unata72@mail.ru

\section{RESUMO}

As seguintes questões são consideradas: a transição para o Padrão Educacional do Estado Federal da nova geração de acordo com o padrão profissional; a análise das Normas Educacionais do Estado Federal na edição anterior e nova; a abordagem de competência para a formação das qualidades profissionais de jovens especialistas; dependência do nível de qualificação no nível de educação e prática; a necessidade de revisar os programas educacionais inovadores, a fim de aumentar a motivação dos alunos para a autoeducação e a formação de competências pessoais que assegurem a demanda de jovens profissionais no mercado de trabalho. Argumentos são dados em favor de métodos de educação orientados para a prática e baseados em projetos na preparação de arquitetos e engenheiros de projeto.

Palavras-chave: Padrão Educacional do Estado Federal, ensino superior, competências pessoais, desenvolvimento de qualidades pessoais, tarefas profissionais complexas.

\section{ABSTRACT}

The following issues are considered: the transition to the Federal State Educational Standard of the new generation in accordance with the professional standard; the Federal State Educational Standards analysis in the previous and new edition; the competence approach to formation the professional qualities of young experts; dependence of the qualification level on the level of education and practice; the need to revise the innovative educational programs in order to increase the motivation of students to self-education and the formation of personal competencies that ensure the demand for young professionals in the labor market. Arguments are given in favor of practice-oriented and project-based methods of education in the preparation of architects and design engineers.

Keywords: Federal State Educational Standard, higher education, personal competences, development of personal qualities, complex professional tasks.

\section{АННОТАЦИЯ}

Рассмотрены вопросы перехода на Федеральный государственный образовательный стандарт нового поколения в соответствии с профессиональным стандартом; анализ ФГОС ВО предыдущей и новой редакции; компентностный подход при формировании профессиональных качеств молодых специалистов; зависимость квалифрикационного уровня от уровня образования и практической 
деятельности; необходимость пересмотра инновационных образовательных программ с целью повышения мотивации обучающихся к самообразованию и формированию личностных компетенций, обеспечивающих востребованность молодых специалистов на рынке труда; приводятся аргументы в пользу практико-ориентированного и проектного методов образования при подготовке архитекторов и инженеров-проектировщиков.

Ключевые слова: Федеральный государственный образовательный стандарт, высшее образование, личностные компетенции, развитие личностных качеств, комплексные профессиональные задачи.

\section{INTRODUCTION}

The vocational education system in Russia strives to meet the requirements of the modern labor market in the construction industry. And the training of professional personnel in demand in this area is a fundamental task of educational organizations (Rogach et al., 2017).

Along with this, there is also a number of problems related to the specialists' training, since the traditional approach to education is now unable to provide modern business with personnel ready to perform specific tasks, especially in the first period of professional activity; weak personal competence, limited thinking, a fear of taking independent nontraditional decisions, defending one's own opinion, and, consequently, the professional lack of demand of young professionals (Akhmetshin et al., 2018). Nowadays, universities produce experts who have a disparate set of professional knowledge and do not represent how they can apply their knowledge at the beginning of the professional activity.

There are serious changes in the system of professional personal training, designed to increase the demand for young professionals in the modern labor market and meet its needs. At the legislative level, the concept of a "Professional Standard" is established, which graduates of educational institutions should correspond to. The basic professional educational programs of higher education are designed to ensure the graduate's mastering of the fundamental foundations of professional activity, which will allow him to work in a wide range of tasks, including innovative and interbranch ones, and to continue education throughout his life (Nakhratova et al., 2017).

\section{MATERIALS AND METHODS}

Programs of vocational training, secondary vocational education, and additional vocational education prepare graduates for professional activities in the framework of specific types of professional activity and performance a certain set of labor functions; therefore, as a rule, they have a direct connection with the professional standard and are formed accordingly (part 8 of Article 73, part 9 of Article 76 Federal Law "On Education in the Russian Federation", 2012). Thus, Article 195.1 of the Labor Code of the Russian Federation defines the qualification of an employee as "the level of knowledge, abilities, professional skills and work experience", and the professional standard defines the qualifications required for the employee to perform a certain type of professional activity, including the performance of a certain labor function (The Labor Code..., 2001).

In turn, the Federal Law "On Education in the Russian Federation" establishes: Formation of the requirements of the Federal State Educational Standards for vocational education to the results of mastering the basic educational programs of professional education in terms of professional competence is carried out on the basis of relevant professional standards (if any) (part 7 of Article 11 Federal Law "On Education in the Russian Federation", 2012).

These innovations and changes are designed to bring labor and education markets closer together under conditions of the formation of a national qualification system, to satisfy the demands of modern society for the formation of all levels of general cultural and social personality qualities which are not directly related to a particular profession, to reflect not only modern representations of existing professions, but also the demands of the labor market in the future. (Simonin et al., 2016)

The main differences between the previous and the new edition of the Federal State 
Educational Standard of Higher Education:

First, the Federal State Educational Standard of Higher Education of the new generation proposes not to use the term "type of professional activity". This is due to the fact that in the professional standard the "type of professional activity" is a unit for uniting similar groups of posts with the purpose of describing their qualifications (in educational standards, this means a group of similar professional tasks). Instead, Federal State Educational Standard of Higher Education will operate with the notion of "type of professional tasks". It can serve to identify the direction (profile) of the educational program, which brings the competency of the graduate closer to certain types of professional activity in the labor market. Directly the list of professional tasks which the graduate is preparing to, as well as objects of professional activity can also be established in the educational program (if there is an orientation (profile) - they are chosen depending on them) (Pilipenko et al., 2016; Zyalaeva, 2014; Semkin and Sharangovich, 2017).

Secondly, innovation is the revision of the approach to competencies. Thus, universal competencies are identical for all training areas of higher education of one level (separately for bachelor, master, specialist and postgraduate). At the same time, the methods of their formation do not have strict regulation and can vary depending on the specifics of the educational area, the enlarged group of specialties and training areas and direct the direction of training or specialty (Pilipenko et al., 2016).

Thus, the professional standard establishes a national qualification framework that provides nine qualification levels, which those from 6 to 9 of corresponding to the level of higher education.

\section{RESULTS AND DISCUSSION:}

However, the framework of qualifications does not establish a rigid relationship between the level of qualifications and the level of higher education. Thus, bachelor's programs correspond to the 6th qualification level, but practical-oriented programs can correspond to the 5th qualification level; the "basic" qualification level corresponding to the master's and specialist's programs is the 7 th one, but in some cases the program data can correspond to the 8th qualification level; the postgraduate programs are conditionally correlated with the 8th and 9th levels of qualification.

Such disposability is due to the fact that the qualification level can be achieved in various ways: in addition to training in the basic professional educational programs, the qualification level can be improved by training on additional professional education programs, internship and practice at the enterprise, accumulation of work experience, during the qualification test and etc.

In order to bring the interests of the labor and education markets closer together and realizing the apparent lack of existing professional standards for this task in full, Federal State Educational Standards of Higher Education set the right for educational organizations to use other tools, in addition to professional standards, to form professional competencies, in particular: foresight analysis data on demanded competencies, the development of the structure of professions in the future, the analysis of the labor market, the compilation of foreign experience, consulting with the leading employers and their associations (Vinichenko et al., 2016a; Vinichenko et al., 2016b).

The proposed changes are aimed not only at establishing a closer link between the labor market and the education system but also designed to maintain the higher education as a mechanism for promoting and developing the professional qualifications which potentially change labor markets. However, there is a concern that blind adherence to professional standards can lead to the revival of narrow-profile departments in higher education institutions. Moreover - it contains the danger of substitution the higher education by certain crafts training (Senashenko, 2015; Blinov et al., 2015; Senashenko and Mednikova, 2015). The necessary conditions for ensuring the quality of higher education are motivated students who have a high-quality general education and are able to master the educational programs of higher education, a motivated teacher of high qualification and a quality educational content (Senashenko, 2015; Sergeeva and Voskrekasenko, 2016; Vinichenko et al., 2016).

All this leads to the need to revise the mechanisms for the formation of professional and personal qualities, improve the quality of graduates' training, the use of various educational methods in the study of various disciplines and the flexibility in developing 
educational programs taking into account the specifics of the market. Currently, there is a fourlevel system of training: a college graduate, a bachelor (or specialist), a master, a postgraduate student (teacher-researcher) (The order..., 2013).

In order to formulate a strategy for improving the quality of training specialists, key areas for interaction between education, science, business and government organizations are determined, and the following educational levels are agreed upon. When mastering the educational program, universal, general professional and professional competencies should be formed by the graduate.

Universal and general professional competences are established by the Federal State Educational Standard of Higher Education in the training area, and a set of professional competencies is formed on the basis of professional standards, relevant to professional activities based on the analysis of the requirements for professional competencies for graduates on the labor market, the synthesis of domestic and foreign experience, consultations with leading employers, associations of employers of the industry, in which graduates are in demand in the training areas and other sources (Order of the Ministry..., 2017). Thus, the educational organization receives considerable freedom in forming the professional competencies of graduates which meet modern business needs, and, consequently, the ability to react more quickly to changes in the market in this area.

The professional standard "Architect" defines the following groups of classes: Architects of buildings and structures (code OK3 2161), Techniques for industrial and civil construction (code OK3 3112), that is, this professional category can include all professionals associated with the architectural and structural design of capital construction facilities (Professional standard..., 2017). As an example, we will describe the generalized labor functions included in the professional standard "Architect" (Table 1). As can be seen from Table 1 , as you progress through the levels of education, there is an increase in the requirements for the specialist.

However, professionality is not only in possession of certain skills in a highly specialized area but also in a wide range of knowledge in other related areas. It is impossible to imagine an architect or a design engineer without understanding the basics of town planning, planning and landscaping, engineering surveys and design of building structures, production technology, economics and management of the construction process (Bondaletova, 2014). The process of forming a specialist in the field of architecture and design of buildings and structures is shown in Figure 1.

The graduate's professionality is affected by many factors which are realized in the educational process. Universal competences (UC) and general professional competences (GPK) are established by Federal State Educational Standard of Higher Education. Competences are formed at all stages of higher education systematically. Professional competencies (PC) are established by the educational organization, in accordance with the demand in the labor market. Personal competences (PC) are not regulated by the standard of training, but they are an integral part of the young specialist. This approach will allow us to work out common vectors for the rational organization of a system of inter-branch and multilevel training, systematically form the competencies of a specialist moving to higher levels of education, and, in turn, encourages the educational organization to search for new organizational forms, educational technologies, new methods of interaction of production and education.

In connection with the above mentioned, the student needs a more meaningful approach to obtaining knowledge, skills, and competencies that meet the requirements of a professional standard. It is necessary to raise the level of internal motivation to the educational process, to create a system of ideological attitudes that increase the value and significance of the students' personal participation in gaining knowledge.

The internal and external motivation of educational activity consists of motives relevant to the content of training activities, respectively, aimed at satisfying or overcoming the frustration of other needs not directly related to the performed activity (Gordeeva and Osin, 2012; Vonog and Yarotskaya, 2017; Vcherashniy et al., 2016). Internal motivation is the basic idea in relation to the educational process, which determines the operating procedure, the degree of intensity and depth of the student's immersion in the educational process. Internal educational motivation is determined by the desire to satisfy 
the need for cognition, achievement, and selfdevelopment (Gordeeva and Osin, 2012; Dobritsa, 2016; Shitov, 2015a). There are various methods of organizing the educational process, designed to increase the personal motivation of students to learn and to diversify the process of knowledge and information.

At present, the idea of practice-oriented and project methods becomes an integrated component of a fully developed and structured education system. But the essence of it remains the same - to stimulate the students' interest in certain problems involving the necessary amount of knowledge, and to solve these problems through project activities, developing a reflex (in the terminology of John Dewey) or a critical thinking (Larionov et al., 2014; Shitov, 2015b).

The teacher is playing a completely new role. He ceases to be a carrier of ready-made information and should encourage students to find a solution to a problem or task. During the joint discussion, the teacher directs the students to an optimal solution. The basis of the method of projects is the development of cognitive skills of students, the ability to independently design their knowledge, navigate the information space as well as develop critical and creative thinking (Larionov et al., 2014). When training specialists, one should not forget about the formation of personal competencies of graduates, designed to improve their competitiveness in the labor market.

As business research and direct communication with business representatives show, the basic discontent of the employer today is not the level of graduates' mastery of the challenge of professional programs, but the low degree of personal competence formation. In addition to the ability to perform professional tasks, the employer wants the graduate to be able to conduct a conversation competently and business correspondence, possess the skills of individual and collective creative activity in solving professional problems, and experience in valuing the company (Abitov et al., 2012). Also, the employer highly appreciates such personal qualities as communication skills, perseverance, purposefulness, mastering the art of selfpresentation, organizational and personal qualities as well as the ability to take independent decisions.

An effective mechanism for the formation and development of personal competencies of university students should be the following basic elements:
1. The general educational system of extracurricular activities aimed at the formation and disclosure of the personal qualities of students;

2. Setting the task of forming personal competencies as a priority for students passing through educational and manufacturing practices;

3. Introduction to the educational process of elective disciplines such as Time Management, Corporate Culture, Team Building, Development of Personal Qualities, Motivation for Success, etc., aimed at the planned and systematic formation of required qualities.

4. Increasing the number of interactive methods of active and interactive learning, including design and practice-oriented training programs.

Forming a portfolio of student's personal achievements is one of three ways to compete in a professional market.

\section{CONCLUSIONS:}

Thus, for the specialists' training in the area of architecture and design of buildings and structures meeting the modern requirements of the labor market, professionally and personally competent, it is optimal to involve students in professional activities at senior courses, combining innovative methods with traditional academic education. It is when the amount of accumulated knowledge has the ability to apply and realize this knowledge in practice, increases the value and usefulness of the material being studied.

It is necessary to change the attitude towards the formation of current study assignments for graduate students, the possibility of solving the end-to-end educational and professional tasks with the subsequent implementation of them in the final qualifying work.

\section{REFERENCES:}

1. Abitov, I. R., Alishev, B. S., Anikeyenok O. A., Vasina V. V., Kashapova G. I., Sageyeva E.R., Fisin Yu.M. Psychological readiness of students to the requirements of the modern labor market: Training manual, Kazan, Russian Federation, 2012.

2. Akhmetshin, E.M., Sharafutdinov, R.I., 
Gerasimov, V.O., Dmitrieva, I.S., Puryaev, A.S., Ivanov, E.A., Miheeva, N. M. Research of human capital and its potential management on the example of regions of the Russian Federation. Journal of Entrepreneurship Education, 2018, 21(2), 114.

3. Blinov, V.I., Batrova, O.F., Yesenina, E.Yu., Faktorovich, A.A. Higher Education in Russia, 2015, 4, 5-14.

4. Bondaletova, N.F. Management of innovative projects in the construction of housing. Materials of the Afanasiev Readings, 2014, 1, 135-139.

5. Dobritsa, V.P. Scientific Journal of the Kursk State University, 2016, 1(37), 86-90.

6. Federal Law "On Education in the Russian Federation" No. 273-\$3 dated December 29, $2012 . \quad$ http://zakon-ob-obrazovanii.ru, accessed August 2018.

7. Gordeeva, T.O., Osin, E.N. Psychological Research, 2012, 5(24), 4.

8. Larionov, V.V., Pak, V.V., Bezvershuk, S.A. Potential of Modern Science, 2014, 5, 72-76.

9. Nakhratova, E.E., Ilina, I.Y., Zotova, A.I., Urzha, O.A., Starostenkov, N.V. Analysis of the relevence of educational programs for applicants and the labor market. European Research Studies Journal, 2017, 20(3A), 144-152.

10. Order of the Ministry of Education and Science of the Russian Federation No. 481 of May 31, 2017 "On approval of the Federal State Educational Standard of Higher Education - bachelor's degree in training area 08.03.01 Construction", 2017. https://rg.ru/2017/06/2/minobr-prikaz481-sitedok.html, accessed August 2018.

11. Pilipenko, S.A., Zhidkov, A.A., Karavaeva, E.V., Serova, A.V. Higher Education in Russia, 2016, 202(6), 5-15.

12. Professional standard "Architect", approved by the Order of the Ministry of Labor and Social Protection of the Russian Federation dated 4 August 2017, No. 616n, 2017. http://fgosvo.ru/uploadfiles/profstandart/10.00 8.pdf, accessed August 2018.

13. Rogach, O.V., Frolova, E.V., Medvedeva, N.V., Ryabova, T.M., Kozyrev, M.S. State and public management of education: Myth or reality. Espacios, 2017, 38(25), 15.

14. Semkin, A.O., Sharangovich, S.N. Modern Education: The Development of Technology and the Content of Higher Professional Education as a Condition for Improving the Quality of Graduates: Materials of the
International Scientific-Methodical Conference, Tomsk: Publishing house TSU of control and radio electronics, 2017, 14-16.

15. Senashenko, V.S. Higher Education in Russia, 2015, 6, 31-36.

16. Senashenko, V.S., Mednikova, T.B. Alma mater (Bulletin of Higher Education), 2015, 5, 60-67.

17. Sergeeva, S.V., Voskrekasenko, O.A. Education Integration, 2016, 20(4), 484-492.

18. Shitov, S.B. Alma Mater (Bulletin of Higher Education), 2015b, 4, 40-44.

19. Shitov, S.B. Bulletin of MSTU "Stankin", 2015a, 2(33), 119-122.

20. Simonin, P.V., Sokolova, A.P., Bogacheva, T.V., Alexeenko, V.B., Vetrova, E.A. Institutionalization of conflict and compromise solutions and social and labor relations in higher educational institutions. Indian Journal of Science and Technology, 2016, 9(19), 93906.

21. The Labor Code of the Russian Federation No. 197-F3 dated December 30, 2001. http://www.trudkod.ru/, accessed August 2018.

22. The order of organization and implementation of educational activities for higher education educational programs bachelor's programs, specialty programs, master's programs, approved by the Minister of Education of the Russian Federation D.V. Livanov, dated December 19, No. 1368, 2013.

http//fgosvo.ru/uploadfiles/proekty\%20doc/P P_Pororg.pdf, accessed August 2018.

23. Vcherashniy, P.M., Gafurova, N.V., Rumyantsev, M.V., Osipenko, O.A. Higher Education in Russia, 2016, 204(8-9), 15-21.

24. Vinichenko, M.V., Frolova, E.V., Kabanova, E.E., Kozyrev, M.S., Evstratova, T.A. The youth employment problems. Journal of Advanced Research in Law and Economics, 2016, 7(2), 378-387.

25. Vinichenko, M.V., Kirillov, A.V., Frolova, E.V., Kaurova, O.V., Makushkin, S.A. Monitoring of working conditions and the nature of their influence on health of students and academic staff. International Journal of Environmental and Science Education, 2016a, 11(11), 4564-4577.

26. Vinichenko, M.V., Makushkin, S.A., Melnichuk, A.V., Frolova, E.V., Kurbakova, S.N. Student employment during college studies and after career start. International Review of Management and Marketing, 2016b, 6(S5), 23-29. 
27. Vonog, V.V., Yarotskaya, L.V. Bulletin of the KSPU named after V.P. Astafieva, 2017, 40(2), 56-62.

28. Zyalaeva, R.G. Integration of Professional Education, Science and Business:

Experience, Problems and Perspectives:
Collection of Papers. of Interregional Scientific-Practical Conference, Cheboksary, Russian Federation, 2014, 50-53. 
Table 1. Description of generalized labor functions included in the professional standard "Architect", according to the levels of education

\begin{tabular}{|c|c|c|c|}
\hline Code & Generalized labor function & $\begin{array}{c}\text { Qualification } \\
\text { level }\end{array}$ & $\begin{array}{l}\text { Requirements for education } \\
\text { and learning }\end{array}$ \\
\hline$A$ & $\begin{array}{l}\text { Development of individual } \\
\text { architectural and space- } \\
\text { planning solutions for the } \\
\text { architectural section of } \\
\text { design documentation for } \\
\text { capital construction } \\
\text { facilities }\end{array}$ & 5 & 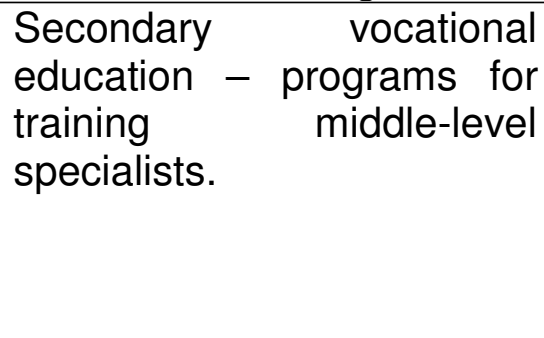 \\
\hline$B$ & $\begin{array}{l}\text { Development of the } \\
\text { architectural section of } \\
\text { design documentation for } \\
\text { capital } \\
\text { facilities }\end{array}$ & 6 & $\begin{array}{l}\text { Higher Education } \\
\text { Bachelor's Degree }\end{array}$ \\
\hline $\mathrm{C}$ & $\begin{array}{l}\text { Management of the } \\
\text { process of architectural and } \\
\text { construction design of } \\
\text { facilities and types of work } \\
\text { associated with the } \\
\text { implementation of capital } \\
\text { construction facilities. }\end{array}$ & 7 & $\begin{array}{l}\text { Higher } \\
\text { specialty and master's } \\
\text { degree. } \\
\text { vocational education - } \\
\text { programs of professional } \\
\text { development at least once } \\
\text { in five years. }\end{array}$ \\
\hline
\end{tabular}




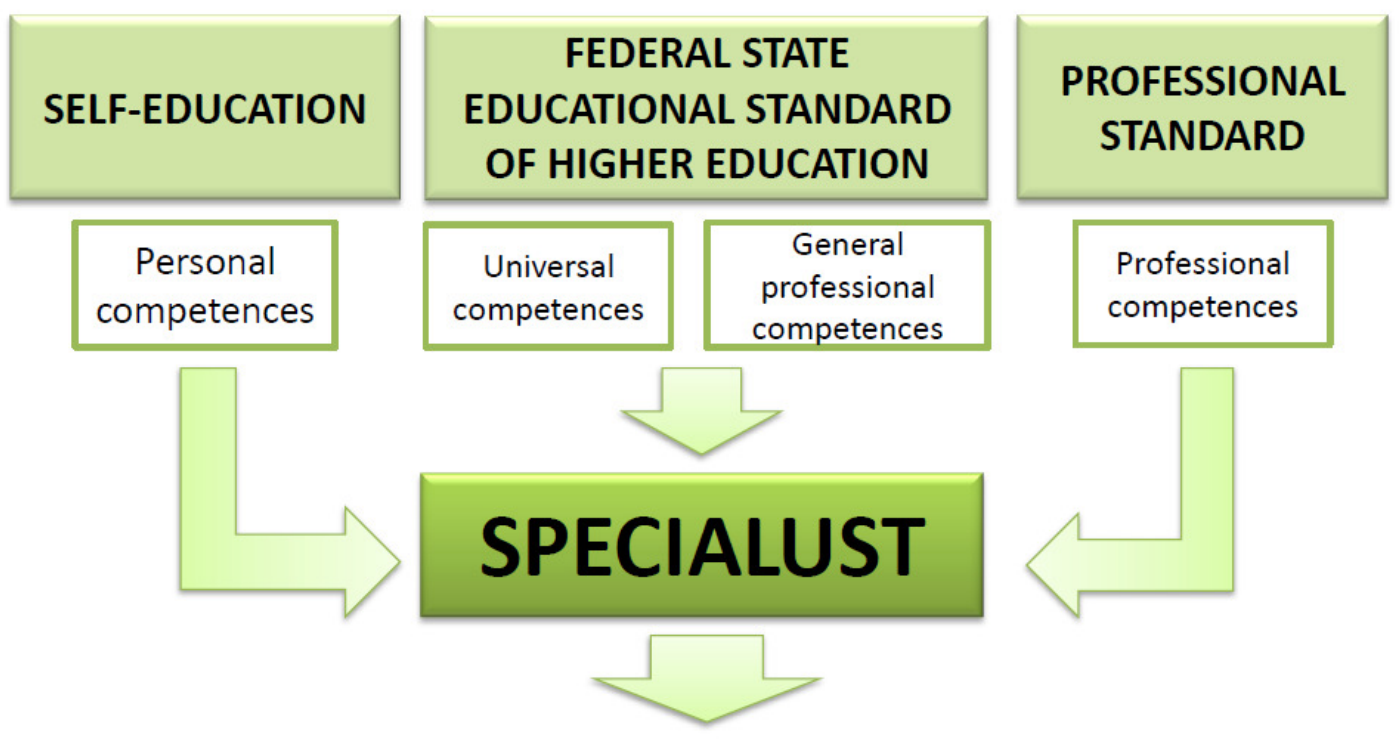

COMPLIANCE WITH SEVERAL PROFESSIONAL STANDARDS
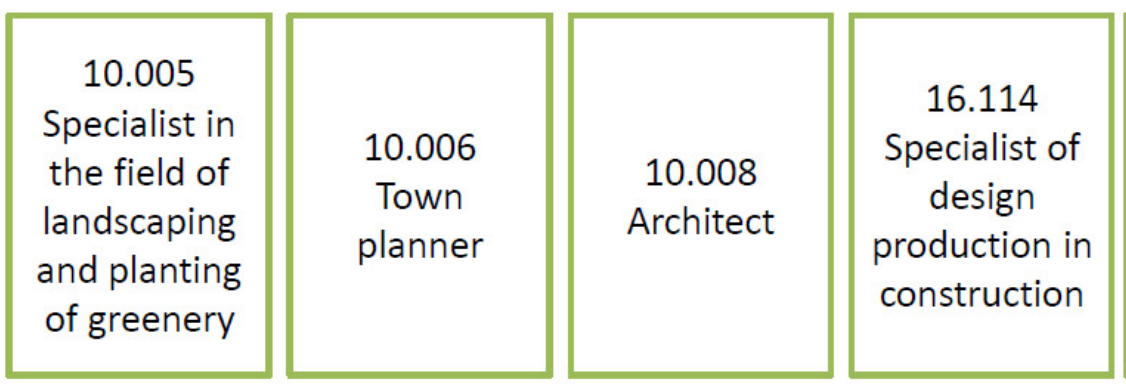

04.002

Specialist in the technical processes of artistic activity

Figure 1. Process of professional formation of a specialist

PERIÓDICO TCHÊ QUÍMICA • www.periodico.tchequimica.com • Vol. 16 N. 31.

- ISSN 1806-0374 (impresso) • ISSN 1806-9827 (CD-ROM) • ISSN 2179-0302 (meio eletrônico) (C) 2019. Porto Alegre, RS. Brasil

The Periódico Tchê Química (ISSN: 1806-0374; 2179-0302) is an open-access journal since 2004. Journal DOI: 10.52571/PTQ. http://www.tchequimica.com. This text was introduced in this file in 2021 for compliance reasons.

(c) The Author(s)

OPEN ACCESS. This article is licensed under a Creative Commons Attribution 4.0 (CC BY 4.0) International License, which permits use, sharing, adaptation, distribution, and reproduction in any medium or format, as long as you give appropriate credit to the original author(s) and the source, provide a link to the Creative Commons license, and indicate if changes were made. The images or other third-party material in this article are included regulation or exceeds the permitted use, you will need to obtain permission directly from the copyright holder. To view a copy of this license, visit http://creativecommons.org/licenses/by/4.0/. 